\title{
EFFECT OF HARVEST TIME ON PHYSICOCHEMICAL QUALITY PARAMETERS, OXIDATION STABILITY, AND VOLATILE COMPOUNDS OF EXTRA VIRGIN OLIVE OIL
}

\author{
S. CeviK ${ }^{\mathrm{a}}$, G. OzKan ${ }^{\mathrm{a}}$, M. Kiralan ${ }^{\mathrm{b} *}$ and A. BayraK ${ }^{\mathrm{c}}$ \\ ${ }^{a}$ Department of Food Engineering, Faculty of Engineering, Suleyman Demirel University, 32260 Isparta. Turkey \\ ${ }^{\mathrm{b}}$ Food Engineering Department, Abant Izzet Baysal University, 14280 Bolu. Turkey \\ ${ }^{c}$ Food Engineering Department, Engineering Faculty, Ankara University, 06110 Ankara. Turkey
}

(Received: 15 August 2012; accepted: 22 October 2012)

\begin{abstract}
The aim of this study was to determine the changes in some physicochemical properties of olives (fruit weight, water content and oil content) and olive oils (total chlorophyll, carotenoid, pheophytin a, peroxide value and free acidity), and in the chemical properties (fatty acids, tocopherols, phenolics, oxidation stability and volatile profiles) of oils during ripening.

Ripening indices (RI) of olive samples were 1.93 (unripe), 4.28 (ripe) and 5.89 (overripe). Most of the mentioned features changed with ripening. During ripening there was a sharp decrease in total chlorophyll, carotenoid and pheophytin a contents. An increase in oleic and linoleic acids and a decrease in palmitic acid were found in the fatty acid composition. Olive oils showed strong relations among oxidation stability, tocopherol content, total phenols content, and antiradical actvity of phenol extracts and these parameters decreased with maturation. Nevertheless, higher amounts of trans-2-hexenal were found in the oil from ripe olives than from unripe and overripe olives. On the other hand, the highest concentration of hexanal was found in the oil from overripe olives.

In general, significant differences were observed in fruit weight, pigments, free acidity, fatty acid, tocopherol, and total phenolics contents, radical scavenger activity, oxidation stability, phenolic profile and volatile profile between the olive oils from the Gemlik cultivar at different stages of maturation.
\end{abstract}

Keywords: olive oil, ripening, quality parameters, oxidation stability, phenolic compounds, volatile compounds

Virgin olive oil is consumed directly in its raw state among vegetable oils. It has a unique characteristic aroma and strong oxidative stability, which are due to the presence of minor components, mainly volatile and phenolic compounds. Volatile compounds are mainly responsible for the aroma, whereas phenolic compounds affect both the taste and especially the oxidation stability of virgin olive oil.

Many researches (PApadopoulos \& Boskou, 1991; Angerosa et al., 1995) have showed the importance of the total or individual phenol contents with regard to olive oil stability. Hydroxytyrosol and its oleosidic forms, protocatechuic and caffeic acids, from virgin olive oil showed antioxidant activity in refined olive oil (PAPAdOPOUlos \& BosKOU, 1991).

Virgin olive oil has a unique aroma, which is the result of a complex of volatile compounds, such as aldehydes, alcohols, ketones, hydrocarbons and esters. Most of them are created through the lipoxygenase pathway from fatty acids. Among these, $\mathrm{C}_{6}$ compounds, the major components of virgin olive oil volatiles, mainly contribute to its green odour notes (KALUA et al., 2005; KANDYLis et al., 2011).

\footnotetext{
* To whom correspondence should be addressed.

Phone: + 90 374-2534640; fax: +90 374-2534558; e-mail: mustafakiralan@yahoo.com
} 
Phenolic and volatile compounds can vary, depending on cultivar, pedoclimatic and cultural practices, as well as the ripening stage. The composition changes during ripening and this influences the perception of sensory qualities. Several studies have already been carried out with the aim of describing the differences of the phenolic and volatile compounds of olives at different ripening stages. Studies on the change of phenolic compounds according to olive ripening have indicated that the concentration of phenols increases to a maximum level at the certain pigmentation stage, and then decreases sharply as ripening progresses (Monteleone et al., 1995). GutiérRez and co-workers (1999) and Rotondi and co-workers (2004) found a decrease in total phenol content of olive oils during ripening. However, major aldehydes, (E)-2-hexenal and hexanal, which are responsible for the green attributes in virgin olive oil, decreased as ripening progressed (GómEz-Rico et al., 2006).

There is limited published information on the phenolics and oxidation stability of Turkish olive oils and no information about volatile compounds of Turkish oils (OCAKOGLU et al., 2009; Dolgun et al., 2010) and the effect of ripening on oxidation stability, phenolic compounds, and volatile compounds of Gemlik olive oil has not been studied. The objectives of this study were to evaluate the changes in some physicochemical properties of olives and olive oils, and chemical properties of oils, especially on contents of fatty acids, tocopherols, phenolics, oxidation stability and volatile profiles of oils from Gemlik olive cultivar, used in olive oil processing in Turkey, during ripening.

\section{Materials and methods}

\subsection{Materials}

1.1.1. Fruit harvesting and processing of olives. Gemlik cultivar was chosen, because most young trees planted in most regions in Turkey were of this cultivar. Olive fruits were selected according to uniformity of size and absence of defects and were picked at three timepoints (unripe, ripe and overripe) according to maturation index from Antalya (West Mediterranean). At each sampling, $3 \mathrm{~kg}$ of olives was processed at a low scale experimental olive mill (Hakki Usta Ogulları, Aydin-Turkey) equipped with a hammer crusher, a vertical malaxator and basket centrifuge. Malaxation (mixing) temperature was set at $32{ }^{\circ} \mathrm{C}$, the olive paste temperature was approximately $27^{\circ} \mathrm{C}$, and the duration of malaxation was $45 \mathrm{~min}$. The obtained oil was filtered using anhydrous sodium sulphate and cotton. The filtered oils were stored in amber glass bottles at $+4{ }^{\circ} \mathrm{C}$ without headspace until the time of analysis. All extractions were done in triplicates for the different ripening indices of each sample and the results were averaged.

\subsection{Methods}

1.2.1. Ripening index (RI). Samples of olives, 100 fruits for each sample, were taken at random, classified into the categories below, and homogenized prior to extraction:

0 . olives with epidermis intense green or dark green,

1. olives with epidermis yellow or yellowish green,

2. olives with epidermis yellowish, with reddish spots or areas,

3. olives with epidermis reddish or light violet,

4. olives with epidermis black and pulp totally white,

5. olives with epidermis black and pulp violet to the midpoint, 
6. olives with epidermis black and pulp violet almost to the pit,

7. olives with epidermis black and pulp totally dark.

With $\mathrm{a}-\mathrm{h}$ being the number of fruits in each category, the $\mathrm{RI}$ is calculated as follows:

$\mathrm{RI}=(\mathrm{a} \times 0+\mathrm{b} \times 1+\mathrm{c} \times 2+\mathrm{d} \times 3+\mathrm{e} \times 4+\mathrm{f} \times 5+\mathrm{g} \times 6+\mathrm{h} \times 7) / 100$

All ripening indices were determined in triplicate for each sample and the results were averaged.

1.2.2. Physicochemical properties of olives. Fifty random fruit samples were evaluated for all physical analysis. Samples were fresh weighted and then dried to constant weight in a ventilated oven at $105^{\circ} \mathrm{C}$ to measure water content and dry weight. Oil content was determined by Soxhlet extraction, using hexane on homogenised flesh of olives dried in an oven at $105{ }^{\circ} \mathrm{C}$. All parameters were determined in triplicate for each sample and the results were averaged.

1.2.3. Determination main quality parameters of olive oil. Acid value, given as $\%$ of oleic acid, and peroxide value (meq $\mathrm{O}_{2} \mathrm{~kg}^{-1}$ oil) were determined by the A.O.C.S. (American Oil Chemist's Society) official methods (1998) Ca 5a-40 and Cd 8-53, respectively. All analysis was carried out in three replications and the results were averaged.

1.2.4. Determination of chlorophyll and carotenoid pigments. A sample of $7.5 \mathrm{~g}$ of oil was weighed exactly, dissolved in cyclohexane, and taken to a final volume of $25 \mathrm{ml}$. The chlorophyll and carotenoid fractions in the absorption spectrum were determined at 670 and $470 \mathrm{~nm}$, respectively (Minguez-Mosquera et al., 1991). Pheophytin a (as Pheo $\alpha$ ) was calculated as described by POKORNY and co-workers (1995). Results are given as milligrams per kg of oil. All analysis was carried out in three replications and the results were averaged.

1.2.5. Determination of total phenols, antiradical activity and oxidation stability. Phenolics of the olive oil samples were isolated from a solution of oil extract in hexane by triple-extraction with water:methanol $(80: 20, \mathrm{v} / \mathrm{v})$. The total phenols (TP) content of the extracts was determined according to the Folin-Ciocalteu spectrophotometric (T70+UV/VIS spectrophotometer, PG Instruments, England) method at $765 \mathrm{~nm}$ (SingLETON \& Rossi, 1965), using a gallic acid calibration curve $\left(\mathrm{r}^{2}=0.999\right)$. The results were expressed as milligrams of gallic acid per kilogram of oil.

The antiradical activity was measured by using the 2,2-diphenyl-1-picrylhydrazyl(DPPH•) radical scavenging method according to DoRMAN and co-workers (2003) and the results were given as $\%$ of inhibition.

Oxidation stability test was performed using the Rancimat equipment at $110{ }^{\circ} \mathrm{C}$ (Metrohm Ltd, Herisau, Swiss) with a continuous air flow of $201 \mathrm{~h}^{-1}$ passing through the samples. The inflection point of the curve was assigned as the induction time and given in hours.

All spectrophotometric analysis above was repeated three times for each type of extract and the results were averaged.

1.2.6. Determination of fatty acid composition. The fatty acid composition of the oil was determined by gas chromatography (GC) as fatty acid methyl esters (FAME). FAME were prepared using saponification/methylation with potassium methylate. The samples were analysed using a Perkin Elmer Autosystem XL gas chromatograph, equipped with a fused 
silica capillary column, Cp WAX 52 CB $(50 \mathrm{~m}$ length $\times 0.32 \mathrm{~mm}$ i.d $\times .1 .2 \mu \mathrm{m})$ and coupled with a flame ionization detector (FID). Carrier gas was helium at a flow rate of $15 \mathrm{~cm} \mathrm{~s}^{-1}$; split ratio was $1 / 20 \mathrm{ml} \mathrm{min}^{-1}$. Injector and detector temperatures were $250^{\circ} \mathrm{C}$. Column temperature was set up according to the following temperature programme: $60{ }^{\circ} \mathrm{C}$, hold for $4 \mathrm{~min} ; 4^{\circ} \mathrm{C}$ $\mathrm{min}^{-1}$ up to $175^{\circ} \mathrm{C}$; hold for $27 \mathrm{~min} ; 4^{\circ} \mathrm{C} \min ^{-1}$ up to $215^{\circ} \mathrm{C}$; hold for $5 \mathrm{~min} ; 4^{\circ} \mathrm{C} \mathrm{min}^{-1}$ up to $240{ }^{\circ} \mathrm{C}$. FAMEs were identified by comparison of their retention times with those of the reference standards (Sigma-Aldrich Chemicals 189-19). The content (percentage by weight) of fatty acids was calculated from their corresponding integration data. All methylations and chromatographic analysis was carried out in three replications and the results were averaged.

1.2.7. Determination of tocopherol composition. Tocopherols $(\alpha-, \beta-, \gamma$ - and $\delta$-tocopherol) were evaluated following the modified A.O.C.S. Official Method Ce 8-89 (A.O.C.S., 1998). Tocopherols were evaluated by high-performance liquid chromatography with direct injection of the olive oil samples into a mixture of heptane:tetrahydrofuran (THF) (95:5) solution. Detection and quantification were carried out with a SCL-10Avp System controller, SIL10ADvp Autosampler, LC-10ADvp pump, CTO-10 Avp column heater, and fluorescence detector with wavelengths set at $295 \mathrm{~nm}$ for excitation and $330 \mathrm{~nm}$ for emission. The $150 \mathrm{~cm}$ $\times 4.6 \mathrm{~mm}$ i.d. column used was filled with Supelcosil Luna, $5 \mu$ (Supelco, Inc. Bellefonte, PA). The mobile phase consisted of heptane/THF $(95: 5, \mathrm{v} / \mathrm{v})$ at a flow rate of $1.2 \mathrm{ml} \mathrm{min} \mathrm{m}^{-1}$ and the injection volume was $10 \mu \mathrm{l}$. The data were integrated and analysed using the Shimadzu Class-VP Chromatography Laboratory Automated Software system. Standard samples of $\alpha$, $\beta, \gamma$, and $\delta$ isomers of tocopherol (Sigma Chemical Co., St. Louis, Mo., USA) were dissolved in hexane and used for the identification and quantification of peaks. The amount of tocopherols in the oils was calculated as $\mathrm{mg}$ tocopherols in $\mathrm{kg}$ oil using external calibration curves $(\mathrm{r}=0.999)$, which were obtained for each tocopherol standard. All chromatographic analysis was carried out in three replications and the results were averaged.

1.2.8. Extraction and determination of phenolic compounds. Phenolics of the olive oil samples were isolated from a solution of oil extract in hexane by triple-extraction with water:methanol $(80: 20, \mathrm{v} / \mathrm{v})$. Detection and quantification were carried out with a SCL10Avp System controller, a SIL-10AD vp Autosampler, a LC-10AD vp pump, a DGU-14a degasser, a CTO-10 A vp column heater, and a diode array dedector with wavelengths set at $278 \mathrm{~nm}$. The $250 \times 4.6 \mathrm{~mm}$ i.d., $5 \mu \mathrm{m}$ column used was filled with Luna Prodigy, $5 \mu$. The flow rate was $1 \mathrm{ml} \mathrm{min}^{-1}$, the injection volume was $10 \mu \mathrm{l}$ and the column temperature was set at 30 ${ }^{\circ} \mathrm{C}$. Gradient elution of two solvents (solvent A: acetic-water $(2: 98, \mathrm{v} / \mathrm{v})$, solvent B: methanol) was used. The data were integrated and analysed using the Shimadzu Class-VP Chromatography Laboratory Automated Software system. The amount of phenolic compounds in the extract was calculated as $\mathrm{mg} / 100 \mathrm{~g}^{-1}$ herb using external calibration curves, constructed for each pure phenolic standard. All extractions and chromatographic analysis was carried out in three replications and the results were averaged.

1.2.9. Extraction and determination of volatile compounds. Approximately $3 \mathrm{~g}$ of the oil samples were inserted into a $20 \mathrm{ml}$ headspace screw top vial and allowed to equilibrate for 10 min at $40{ }^{\circ} \mathrm{C}$. The headspace of the samples was extracted for $40 \mathrm{~min}$ at $40{ }^{\circ} \mathrm{C}$ using a CTC Combi PAL auto sampler equipped with $75 \mu \mathrm{m}$ carboxen/polydimethylsiloxane (CAR/ PDMS) solid phase microextraction (SPME) fibre. The volatile compounds were desorbed 
by directly inserting the fibre for $10 \mathrm{~min}$ into the injection port of the gas chromatography maintained at $250^{\circ} \mathrm{C}$.

Analyses of volatile compounds were performed using an Agilent model 7890 Series gas chromatograph in combination with a CTC Combi PAL autosampler and an Agilent 5975 $\mathrm{N}$ mass selective detector. The compounds were separated in a GC column (DB-624, J\&W Scientific, $30 \mathrm{~m}, 0.25 \mathrm{~mm}$ i.d., $1.4 \mu \mathrm{m}$ film thickness) set up at the following temperature programme: $40{ }^{\circ} \mathrm{C}$, hold for $5 \mathrm{~min} ; 3^{\circ} \mathrm{C} \mathrm{min}-1$ up to $110{ }^{\circ} \mathrm{C} ; 4{ }^{\circ} \mathrm{C} \min ^{-1}$ up to $150{ }^{\circ} \mathrm{C} ; 10{ }^{\circ} \mathrm{C}$ $\mathrm{min}^{-1}$ up to $210^{\circ} \mathrm{C}$, hold for $12 \mathrm{~min}$. The temperatures for the injection port, ion source, quadrupole and interface were set at $250,230,150$ and $240{ }^{\circ} \mathrm{C}$, respectively. Mass spectra were obtained in the electron impact at $70 \mathrm{eV}$ in full scan and a scan range from $\mathrm{m} / \mathrm{z} 41-400$. Identification of the constituents was based on a comparison of the retention times with those of authentic reference compounds, by means of their Kovats Index (KI) relative to the series of $n$-hydrocarbons (C4-C20); and on computer matching against NIST and WILEY library mass spectra. All extractions and chromatographic analysis was carried out in three replications and the results were averaged.

1.2.10. Statistical analysis. Results of the research were tested for statistical significance by one-way ANOVA. Differences were considered statistically significant at the $\mathrm{P} \leq 0.01$ level.

\section{Results and discussion}

Some physicochemical parameters of olives having different RI are shown in Table 1. Ripening indices of olives were 1.93 (unripe), 4.28 (ripe) and 5.89 (overripe). A decrease was observed in the water and oil content of olives from the last harvesting period and total oil content of olives increased together with the increase of maturity. Differences on water content and oil content on dry basis may be from the result of ripening (MотіLVA et al., 2000). While ripening index of olives was found to be statistically important at the $0.05 \%$ level, oil content on dry basis was not. Differences on water content of ripe and overripe samples were significantly different, but unripe was not significantly different from ripe or overripe. In addition, the difference between fruit weights of ripe and overripe olives was not found important at the $0.05 \%$ level, but unripe samples had the lowest weight.

Table 1. Some physicochemical properties of olives of different maturation levels

\begin{tabular}{lccc}
\hline & \multicolumn{3}{c}{ Harvesting period } \\
Properties & Unripe & Ripe & Overripe \\
\cline { 2 - 4 } & & Ripening index (RI) & $5.89 \mathrm{a}$ \\
\hline Fruit weight $(\mathrm{g})$ & $1.93 \mathrm{c}^{*}$ & $4.28 \mathrm{~b}$ & $4.01 \pm 0.52 \mathrm{a}$ \\
Water content $(\%)$ & $3.31 \pm 0.47 \mathrm{~b}$ & $4.10 \pm 0.62 \mathrm{a}$ & $46.74 \pm 2.47 \mathrm{~b}$ \\
Oil content on dry basis $(\%)$ & $52.82 \pm 1.58 \mathrm{ab}$ & $55.20 \pm 5.10 \mathrm{a}$ & $65.67 \pm 1.42 \mathrm{a}$ \\
\hline
\end{tabular}

*Significant at $0.05 \%$ level, different letters indicate the statistical difference within rows 
The results for some physicochemical properties of olive oils are shown in Table 2. Total chlorophyll, total carotenoid and pheophytin a contents of olive oils decreased markedly during ripening. Differences in pigmentation have been statistically significant. GUTIÉRREZ and co-workers (1999) found a decrease in total chlorophyll and carotenoid contents with maturation. A similar trend was observed by OZKAN and co-workers (2008) and Dolgun and co-workers (2010).

Table 2. Some physicochemical properties of olive oils at different stages of ripening

\begin{tabular}{lccc}
\hline \multirow{2}{*}{ Properties } & \multicolumn{3}{c}{ Harvesting period } \\
\cline { 2 - 4 } & Unripe & Ripe & Overripe \\
\hline Total chlorophyll $\left(\mathrm{mg} \mathrm{kg}^{-1}\right)$ & $2.276 \pm 0.043 \mathrm{a}^{*}$ & $0.998 \pm 0.034 \mathrm{~b}$ & $0.457 \pm 0.139 \mathrm{c}$ \\
Total carotenoid $\left(\mathrm{mg} \mathrm{kg}^{-1}\right)$ & $1.383 \pm 0.015 \mathrm{a}$ & $0.862 \pm 0.014 \mathrm{~b}$ & $0.438 \pm 0.048 \mathrm{c}$ \\
Pheophytin a (as Pheo $\alpha)\left(\mathrm{mg} \mathrm{kg}^{-1}\right)$ & $3.821 \pm 0.020 \mathrm{a}$ & $0.794 \pm 0.000 \mathrm{~b}$ & $0.371 \pm 0.009 \mathrm{c}$ \\
Peroxide value $\left(\mathrm{meq} \mathrm{O}_{2} \mathrm{~kg}^{-1}\right.$ oil) & $8.20 \pm 0.12 \mathrm{a}$ & $8.02 \pm 0.20 \mathrm{a}$ & $8.05 \pm 0.11 \mathrm{a}$ \\
Free acidity (as \% oleic acid) & $0.52 \pm 0.00 \mathrm{c}$ & $0.67 \pm 0.00 \mathrm{~b}$ & $0.93 \pm 0.01 \mathrm{a}$ \\
\hline
\end{tabular}

*Significant at $0.05 \%$ level, different letters indicate the statistical difference within rows

The peroxide value changed from 8.02 to 8.20 meq $\mathrm{O}_{2} / \mathrm{kg}^{-1}$ oil during ripennig and no significant differences were observed with maturation. The peroxide values of these oils are below the limit of 20 meq $\mathrm{kg}^{-1}$. According to the literature, there were no changes in peroxide value of oils of Nostrana di Brisighella cultivar with maturation (RоTONDI et al., 2004). Free acidity content ranged between 0.52 and 0.93 (as oleic acid \%), only one sample from the last harvesting period exceeded the limit of 0.8 , which is an accepted standard for extra natural virgin olive oil (ANON., 2006). Differences among acidities were found to be statistically important at the $0.05 \%$ level and similar behaviour with ripening was reported by GUTIÉRREZ and co-workers (1999) and RoTONDI and co-workers (2004).

Table 3. Fatty acid composition of virgin olive oils extracted from Gemlik olives at different stages of ripening

\begin{tabular}{lccc}
\hline Fatty acids (\%) & \multicolumn{3}{c}{ Harvesting period } \\
\cline { 2 - 4 } & Unripe & Ripe & Overripe \\
\hline Palmitic acid (C16:0) & $20.15 \pm 0.17 \mathrm{a} *$ & $14.01 \pm 0.07 \mathrm{c}$ & $17.99 \pm 0.24 \mathrm{~b}$ \\
Palmitoleic acid (C16:1) & $1.88 \pm 0.03 \mathrm{a}$ & $1.47 \pm 0.01 \mathrm{~b}$ & $1.96 \pm 0.07 \mathrm{a}$ \\
Heptadecanoic acid (C17:0) & $0.29 \pm 0.02 \mathrm{a}$ & $0.00 \pm 0.00 \mathrm{~b}$ & $0.00 \pm 0.00 \mathrm{~b}$ \\
Stearic acid (C18:0) & $4.42 \pm 0.08 \mathrm{a}$ & $2.18 \pm 0.03 \mathrm{c}$ & $3.72 \pm 0.43 \mathrm{~b}$ \\
Oleic acid (C18:1n9) & $58.33 \pm 0.39 \mathrm{~b}$ & $66.37 \pm 0.04 \mathrm{a}$ & $56.76 \pm 1.52 \mathrm{~b}$ \\
cis-Vaccenic acid (C18:1n-7) & $3.56 \pm 0.02 \mathrm{~b}$ & $3.54 \pm 0.03 \mathrm{~b}$ & $4.17 \pm 0.30 \mathrm{a}$ \\
Linoleic acid (C18:2n6) & $9.17 \pm 0.01 \mathrm{c}$ & $10.18 \pm 0.02 \mathrm{~b}$ & $13.64 \pm 0.41 \mathrm{a}$ \\
Arachidic acid (C20:0) & $0.27 \pm 0.02 \mathrm{a}$ & $0.00 \pm 0.00 \mathrm{~b}$ & $0.00 \pm 0.00 \mathrm{~b}$ \\
\hline
\end{tabular}

*Significant at $0.05 \%$ level, different letters indicate the statistical difference within rows 
The fatty acid compositions varied among samples from different harvesting period (Table 3). The major fatty acids were oleic (56.76-66.37\%), palmitic (14.01-20.15\%) and linoleic (9.17-13.64\%). Minor ones were stearic, cis-vaccenic (C18:1n-7), palmitoleic, heptadecanoic and arachidic acids. These results are in agreement with those obtained by GUTIÉRREZ and co-workers (1999), OZKAN and co-workers (2008) and Dolgun and co-workers (2010).

The $\alpha$-, $\beta$ - and $\gamma$-tocopherol contents changed with maturation and ranged between $128.35-154.50,0.90-5.45$ and $0.80-1.20 \mathrm{ppm}$ in oil, respectively (Table 4). These values were similar for organic and conventional Gemlik olive oils (OZKAN et al., 2008; DoLGUN et al., 2010). Particularly important was the decrease in the amount of $\alpha$-, $\beta$ - and $\gamma$-tocopherol contents obtained for Gemlik olive cultivar from second and third harvesting period as compared to that obtained from the first harvesting period of the same cultivar. However, $\gamma$-tocopherol decreased only slightly during ripening. Statistically important differences were found for $\beta$-tocopherols at a $0.05 \%$ level. While a-tocopherol of unripe and $\gamma$-tocopherol of overripe samples were statistically different, there were no differences between $\alpha$ - tocopherols of ripe and overripe samples and $\gamma$-tocopherols of unripe and ripe ones. GUTIÉRREz and coworkers (1999) found a decrease in $\alpha$-tocopherol content of the oils from Picual cultivar during ripening.

Table 4. Tocopherol content (ppm) in the virgin olive oils extracted from Gemlik olives at different stages of ripening

\begin{tabular}{lccc}
\hline Tocopherols $\left(\mathrm{mg} \mathrm{kg}^{-1}\right.$ oil) & \multicolumn{3}{c}{ Harvesting period } \\
\cline { 2 - 4 } & Unripe & Ripe & Overripe \\
\hline$\alpha$-Tocopherol & $154.50 \pm 0.30 \mathrm{a} *$ & $128.35 \pm 2.25 \mathrm{~b}$ & $129.70 \pm 0.60 \mathrm{~b}$ \\
$\beta$-Tocopherol & $5.45 \pm 0.05 \mathrm{a}$ & $1.00 \pm 0.00 \mathrm{~b}$ & $0.90 \pm 0.00 \mathrm{c}$ \\
$\gamma$-Tocopherol & $1.20 \pm 0.00 \mathrm{a}$ & $1.10 \pm 0.00 \mathrm{a}$ & $0.80 \pm 0.00 \mathrm{~b}$ \\
\hline
\end{tabular}

*Significant at $0.05 \%$ level, different letters indicate the statistical difference within rows

Changes in the content of total phenols, antiradical and oxidation stability of oils are shown in Table 5. The total phenol content of oils ranged from 166.25 to $227.80 \mathrm{mg}$ gallic $\mathrm{acid} / \mathrm{kg}$ oil. These results were similar for organic and conventional Gemlik olive oils (OzKAN et al., 2008; Dolgun et al., 2010). Statistically significant differences were found among total phenol contents of olive oils at different ripening stage $(\mathrm{P} \leq 0.05)$. The highest total phenol content was found in unripe oil and it decreased during ripening in our study. Our results are in agreement with the findings of GIMENO and co-workers (2002). The oils showed high initial concentration of $o$-diphenols, which underwent a significant decrease until the second and third harvesting period. These results showing the loss of $o$-diphenols as ripening progresses are in accordance with the data of RотоNDI and co-workers (2004). 
Table 5. Total phenol content, radical scavenger activity and oxidation stability of olive oils at different stages of ripening

\begin{tabular}{lccc}
\hline Properties & \multicolumn{3}{c}{ Harvesting period } \\
\cline { 2 - 4 } & Unripe & Ripe & Overripe \\
\hline Total phenolics (mg GAE/kg oil) & $227.80 \pm 8.79 \mathrm{a}^{*}$ & $177.35 \pm 3.57 \mathrm{~b}$ & $166.25 \pm 1.47 \mathrm{c}$ \\
Radical scavenger activity (\%) & $84.14 \pm 0.14 \mathrm{a}$ & $82.00 \pm 0.56 \mathrm{~b}$ & $80.21 \pm 0.14 \mathrm{c}$ \\
Oxidation stability (h) & $35.87 \pm 0.27 \mathrm{a}$ & $22.05 \pm 0.40 \mathrm{c}$ & $23.15 \pm 0.08 \mathrm{~b}$ \\
\hline
\end{tabular}

*Significant at $0.05 \%$ level, different letters indicate the statistical difference within rows

Antiradical activity of oil samples varied with respect to the ripening of olive fruits and statistically important differences were found among them. The strongest free radicalscavenger effect was determined in oils from the first harvesting time and the lowest effect was in the oils from the second and third harvesting time. BonOLI and co-workers (2004) found that antiradical power of olive oils decreased when ripening increased.

Oxidation stability of oils also varied from 35.87 to 22.05 hours at $110^{\circ} \mathrm{C}$. In general, induction periods of oils decreased as fruits ripened. The oils showed a sharp loss of stability after the first harvest period. The results were in agreement with results from the literature (GuTiÉrRez et al., 1999; Rotondi et al., 2004).

Tyrosol, hydroxytyrosol, vanillin, vanillic acid, $p$-coumaric acid, ferulic acid, cinnamic acid, quercetin and luteolin were found as pheolics in olive oils of Gemlik cultivar at different stages of ripening (Table 6). The contents of all phenolics were significantly affected by the ripening.

Table 6. Phenolic compounds of oils at different stages of ripening

\begin{tabular}{lccc}
\hline Phenolics $\left(\mathrm{mg} \mathrm{kg}^{-1}\right.$ oil) & \multicolumn{3}{c}{ Harvesting period } \\
\cline { 2 - 4 } & Unripe & Ripe & Overripe \\
\hline Hydroxytyrosol & $0.35 \pm 0.00 \mathrm{c}^{*}$ & $0.80 \pm 0.01 \mathrm{~b}$ & $0.91 \pm 0.00 \mathrm{a}$ \\
Tyrosol & $1.91 \pm 0.00 \mathrm{a}$ & $1.91 \pm 0.00 \mathrm{a}$ & $0.69 \pm 0.01 \mathrm{~b}$ \\
Vanillin & $0.69 \pm 0.00 \mathrm{a}$ & $0.52 \pm 0.00 \mathrm{~b}$ & $0.41 \pm 0.00 \mathrm{c}$ \\
Vanillic acid & $1.63 \pm 0.00 \mathrm{a}$ & $0.37 \pm 0.00 \mathrm{~b}$ & $0.16 \pm 0.00 \mathrm{c}$ \\
$p$-Coumaric acid & $0.09 \pm 0.00 \mathrm{a}$ & $0.04 \pm 0.00 \mathrm{c}$ & $0.08 \pm 0.00 \mathrm{~b}$ \\
Ferulic acid & $0.08 \pm 0.00 \mathrm{a}$ & $0.00 \pm 0.00 \mathrm{~b}$ & $0.00 \pm 0.00 \mathrm{~b}$ \\
Cinnamic acid & $0.07 \pm 0.00 \mathrm{a}$ & $0.05 \pm 0.00 \mathrm{~b}$ & $0.02 \pm 0.00 \mathrm{c}$ \\
Quercetin & $0.04 \pm 0.00 \mathrm{a}$ & $0.03 \pm 0.00 \mathrm{~b}$ & $0.01 \pm 0.00 \mathrm{c}$ \\
Luteolin & $0.34 \pm 0.01 \mathrm{c}$ & $1.06 \pm 0.00 \mathrm{a}$ & $0.39 \pm 0.00 \mathrm{~b}$ \\
\hline
\end{tabular}

*Significant at $0.05 \%$ level, different letters indicate the statistical difference within rows

The content of tyrosol ranged from 0.69 to $1.91 \mathrm{mg} \mathrm{kg}^{-1}$ and hydroxytyrosol content varied between 0.35 and $0.91 \mathrm{mg} \mathrm{kg}^{-1}$. Our results were lower than data of OCAKOGLU and co-workers (2009) for Gemlik olive oil. Hydroxytyrosol content of oils increased with ripening, however, tyrosol decreased at the last harvest time. Concentration of hydroxytyrosol is generally found low in freshly extracted oils (EsTI et al., 1996). Concentrations of vanillin 
(from 0.41 to 0.69 ) were high at the oils from first harvesting olives, whereas were low at the oils from second and last harvesting. Morello and co-workers (2004) also found that the content of vanillin decreased when ripening increased.

Some phenolic acids were already described in the Turkish olive oils, such as vanillic, p-coumaric, ferulic and cinnamic acids (OcAKoglu et al., 2009). Vanillic acid is the major phenolic acid found in oil samples analysed. Vanillic acid concentration decreased with maturation in olive oil samples. Our results are in agreement with the results of MoreLLO and co-workers (2004). Interestingly, ferulic acid was found in one oil sample only from unripe olives first harvested.

Quercetin and luteolin were determined as flavonoids in olive oils. The quercetin concentration of oils was noticeably lower and showed little variations during maturation as mentioned by BouAzIz and co-workers (2004). The luteolin content showed increase in oils from first harvest to second harvest time, but after that it had sharply decreased. MorelLo and co-workers (2004) observed varying luteolin contents at different maturation levels, but no linear correlation was found between its content and the maturation level.

The volatile compounds are shown in Table 7. Major compounds are $\mathrm{C}_{6}$ aldehydes, hexanal, and trans-2-hexenal and their amounts changed with maturation. Trans-2-hexenal showed the highest amount at the second harvest time, however, hexanal was the highest at the last harvest time. The contents of these compounds varied during ripening, but a clear trend was not observed for the Gemlik cultivar. KALUA and co-workers (2005) have reported similar trends for Leccino, Barnea, Manzanilla, Mission, Corregiola and Paragon. The content of trans-2-hexenal reached its maximum level at the second harvest time and then decreased in Cerasuola, Biancolilla and Nocellara del Belice olive cultivars (BACCOURI et al., 2008). This decrease after reaching a maximum level of trans-2-hexenal may be explained by a lower activity of the enyzmes involved in their production (ANGEROSA \& BASTI, 2001).

The minor $\mathrm{C}_{6}$ esters cis-3-hexenyl acetate and hexyl acetate were found in the oil samples. The amount of these esters increased from the first harvest to the second one in the oil samples. KANDYLIS and co-workers (2011) also found a significant increase in the amount of these esters from the first harvested olives to the second harvested ones in Cretan and Tunisian olive oils.

1-penten-3-one and trans-2-pentenal are $\mathrm{C}_{5}$ compounds contributing fruity, sweet, and pleasant attributes to olive oil (BACCOURI et al., 2008). 1-penten-3-one is basically found in oils from unripe olives (KaLUA et al., 2005). The content of 1-penten-3-one ranged between 5.25-10.30\%. 1-penten-3-one decreased markedly during olive ripening. Similar behaviour was observed for 1-penten-3-one of the oils of cultivars of Nocellara del Belice and Sfax (non-irrigated) and for trans-2-pentenal of the oils of Chétoui (irrigated) and Sfax olive cultivars during ripening (BACCOURI et al., 2008; KAndylis et al., 2011). Pentene dimers, 3-ethyl-1,5-octadienes, were also determined in olive oil samples. The content of these compounds decreased during the maturation process in oil samples. Work by BACCOURI and co-workers (2008) demonstrated that these dimers were affected by and decreased with maturation. 
Table 7. Volatile aroma compounds of oils at different stages of ripening

\begin{tabular}{llccc}
\hline $\mathrm{KI}^{\mathrm{a}}$ & Volatiles (\%) & \multicolumn{3}{c}{ Harvesting period } \\
\cline { 3 - 5 } & & Unripe & Ripe & Overripe \\
\hline 717 & 2-Ethyl furan & $9.56 \pm 0.12 \mathrm{~b} *$ & $8.31 \pm 0.36 \mathrm{c}$ & $16.17 \pm 0.06 \mathrm{a}$ \\
726 & 1-Penten-3-one & $10.30 \pm 0.86 \mathrm{a}$ & $5.25 \pm 0.14 \mathrm{~b}$ & $5.52 \pm 0.03 \mathrm{~b}$ \\
791 & 3-Methyl-1-butanol & $1.00 \pm 0.01 \mathrm{a}$ & $0.65 \pm 0.03 \mathrm{~b}$ & $0.60 \pm 0.01 \mathrm{c}$ \\
800 & Octane & $1.03 \pm 0.01 \mathrm{~b}$ & $0.80 \pm 0.03 \mathrm{c}$ & $2.02 \pm 0.01 \mathrm{a}$ \\
808 & trans-2-Pentenal & $1.20 \pm 0.05 \mathrm{a}$ & $0.44 \pm 0.00 \mathrm{~b}$ & $0.00 \pm 0.00 \mathrm{c}$ \\
841 & Hexanal & $26.20 \pm 0.45 \mathrm{~b}$ & $22.81 \pm 0.41 \mathrm{c}$ & $33.49 \pm 0.11 \mathrm{a}$ \\
898 & p-Xylene & $2.96 \pm 0.13 \mathrm{a}$ & $2.02 \pm 0.04 \mathrm{~b}$ & $1.63 \pm 0.01 \mathrm{c}$ \\
909 & trans-2-Hexenal & $19.90 \pm 0.31 \mathrm{c}$ & $38.70 \pm 0.17 \mathrm{a}$ & $21.52 \pm 0.02 \mathrm{~b}$ \\
946 & 3-Ethyl-1,5-octadiene & $2.67 \pm 0.04 \mathrm{a}$ & $1.66 \pm 0.00 \mathrm{~b}$ & $1.67 \pm 0.01 \mathrm{~b}$ \\
956 & 3-Ethyl-1,5-octadiene & $2.00 \pm 0.04 \mathrm{a}$ & $0.97 \pm 0.00 \mathrm{~b}$ & $0.69 \pm 0.01 \mathrm{c}$ \\
977 & 2,4-Hexadienal & $6.74 \pm 0.02 \mathrm{a}$ & $4.59 \pm 0.05 \mathrm{~b}$ & $3.57 \pm 0.04 \mathrm{c}$ \\
1003 & Myrcene & $1.52 \pm 0.02 \mathrm{a}$ & $0.78 \pm 0.02 \mathrm{~b}$ & $0.52 \pm 0.01 \mathrm{c}$ \\
1006 & 2-Pentyl furan & $0.96 \pm 0.01 \mathrm{a}$ & $0.51 \pm 0.01 \mathrm{~b}$ & $0.30 \pm 0.00 \mathrm{c}$ \\
1041 & cis-3-Hexenyl acetate & $0.63 \pm 0.00 \mathrm{c}$ & $1.85 \pm 0.04 \mathrm{a}$ & $1.49 \pm 0.00 \mathrm{~b}$ \\
1045 & Hexyl acetate & $0.00 \pm 0.00 \mathrm{c}$ & $0.86 \pm 0.02 \mathrm{a}$ & $0.52 \pm 0.00 \mathrm{~b}$ \\
1048 & Limonene & $2.46 \pm 0.02 \mathrm{a}$ & $1.55 \pm 0.03 \mathrm{~b}$ & $1.20 \pm 0.01 \mathrm{c}$ \\
1155 & Allo-ocimene & $0.27 \pm 0.00 \mathrm{~b}$ & $0.27 \pm 0.02 \mathrm{~b}$ & $0.30 \pm 0.01 \mathrm{a}$ \\
1213 & Phenylethyl alcohol & $7.36 \pm 0.14 \mathrm{a}$ & $6.46 \pm 0.83 \mathrm{ab}$. & $5.85 \pm 0.18 \mathrm{~b}$ \\
\hline
\end{tabular}

* Significant at $0.05 \%$ level, different letters indicate the statistical difference within rows; ${ }^{a} \mathrm{KI}$ : Kovats index calculated for DB-624 capillary column (J\&W Scientific: $30 \mathrm{~m}, 0.25 \mathrm{~mm}$ i.d., $1.4 \mu \mathrm{m}$ film thickness) installed on a gas chromatograph equipped with a mass-selective detector; ${ }^{b}$ Isomers of these compounds were not identified

\section{Conclusions}

In conclusion, some properties of Gemlik olive and olive oil were influenced by maturation. The oil content (\%) and free acidity increased during the period of ripening, whilst the amounts of total phenols and tocopherols and the free radical scavenger activity decreased. The highest oxidation stability was found in the oil from unripe olives. The peroxide value showed no changes during the ripening stages. Important losses in chlorophyll, carotenoid, and pheophytin a content of oils have also been observed during maturation. Although most of the fatty acid contents did not demonstrate a significant variation, linoleic acid content increased regularly. Phenolic and volatile compounds were also affected by ripening. The hydroxytyrosol content of the oils increased with ripening, however, the amount of tyrosol decreased at the last harvest time. Trans-2-hexenal was found to be the major volatile compound in the oils collected in the second harvest period. 
This study was supported financially by the TÜBİTAK (Project: 2209-National/International Research Projects Fellowship Programme for Undergraduate Student) of Suleyman Demirel University, Isparta, Turkey

\section{References}

Angerosa, F., D’alexandro, N., Konstantinou, P. \& Di Giacinto, L. (1995): Evaluation of phenolic compounds in virgin olive oil. J. Agric. Fd Chem., 43, 1802-1807.

Angerosa, F. \& Basti, C. (2001): Olive oil volatile compounds from the lipoxygenase pathway in relation to fruit ripeness. It. J. Fd Sci., 13, 421-428.

A.O.C.S. (1998): Methods Ca 5a-40, Cd 8-53, Ce 8-89. Official Methods and Recommended Practices of the American Oil Chemist's Society, 5th ed. Champaign, Illinois, U.S.A.

AnON. (2006): Trade standard applying to olive oils and olive-pomace oils. COI/T.15/NC No. 3/Rev. 224 November 2006.

Baccouri, O., Bendini, A., Cerretani, L., Guerfel, M., Baccouri, B., Lercker, G., Zarrouk, M. \& Miled, D.D.B. (2008): Comparative study on volatile compounds from Tunisian and Sicilian monovarietal virgin olive oils. Fd Chem., 111, 322-328.

Bonoli, M., Bendini, A., Cerretani, L., Lercker, G. \& Toschi, T.G. (2004): Qualitative and semiquantitative analysis of phenolic compounds in extra virgin olive oils as a function of the ripening degree of olive fruits by different analytical techniques. J. Agric. Fd Chem., 52, 7026-7032.

Bouaziz, M., Сhamkha, M. \& Sayadi, S. (2004): Comparative study on phenolic content and antioxidant activity during maturation of the olive cultivar Chemlali from Tunisia. J. Agric. Fd Chem., 52, 5476-5481.

Dolgun, O., OzKan, G. \& Erbay, B. (2010): Comparison of olive oils derived from certified organic and conventional agricultural methods. Asian J. Chem., 22, 2339-2348.

Dorman, H.J.D., Peltoketo, A., Hiltunen, R. \& Tikkanen, M.J. (2003): Characterization of antioxidant properties of de-odourized aqueous extracts from selected Lamiaceae herbs. Fd Chem., 83, 255-262.

Esti, M., Cinquanta, L., Carrone, A., Trivisonno, M.C., La Notte, E. \& Gambacorta, G. (1996): Composti antiossidanti e parametri qualitativi di oli vergini di oliva prodotti in Molise (Antioxidative compounds and quality parameters in virgin olive oils produced in Molise.) Riv. Ital. Sostanze Grasse, 73, 147-150.

Gimeno, E., Castellote, A.I., Lamuela-Raventos, R.M., De La Torre, M.C. \& Lopez-Sabater, M.C. (2002): The effects of harvest and extraction methods on the antioxidant content (phenolics, $\alpha$-tocopherol, and $\beta$-carotene) in virgin olive oil. Fd Chem., 78, 207-211.

Gómez-Rico, A., Salvador M.D., La Greca, M. \& Fregapane, G. (2006): Phenolic and volatile compounds of extra virgin olive oil (Olea europaea L. Cv. Cornicabra) with regard to fruit ripening and irrigation management. $J$. Agric. Fd Chem., 54, 7130-7136.

Gutiérrez, F., Jímenez, B., Ruíz, A. \& Albi, M.A. (1999): Effect of olive ripeness on the oxidative stability of virgin olive oil extracted from the varieties Picual and Hojiblanca and on the different components involved. $J$. Agric. Fd Chem., 47, 121-127.

Kalua, C.M., Allen, M.S., Bedgood, JR D.R., Bishop, A.G. \& Prenzler, P.D. (2005): Discrimination of olive oils and fruits into cultivars and maturity stages based on phenolic and volatile compounds. J. Agric. Fd Chem., 53, 8054-8062.

Kandylis, P., Vekiari, A.S., Kanellaki, M., Kamoun, N.G., Msallem, M. \& Kourkoutas, Y. (2011): Comparative study of extra virgin olive oil flavor profile of Koroneiki variety (Olea europaea var. Microcarpa alba) cultivated in Greece and Tunisia during one period of harvesting. LWT - Fd Sci. Technol., 44, 1333-1341.

Minguez-Mosquera, M.I., Rejano-Navarro, L., Gandul-Rojas, B., Sanchez-Gomez, A.H. \& Garrido-Fernandez, I. (1991): Color-pigment correlation in virgin olive oil. J. Am. Oil Chem. Soc., 68, 332-336.

Monteleone, E., Caporale, G., Lencioni, L., Favati, F. \& Bertuccioli, M. (1995): Optimization of virgin olive oil quality in relation to fruit ripening and storage. -in: Charalambous, G. (Ed.) Food flavors: generation, analysis and process influence. Elsevier Science, Amsterdam, pp. 397-418.

Morello, J.R., Romero, M.P. \& Motilva, M.J. (2004): Effect of the maturation process of the olive fruit on the phenolic fraction of drupes and oils from Arbequina, Farga, and Morrut cultivars. J. Agric. Fd Chem., 52, 6002-6009.

Motilva, M.J., Tovar, M.J., Romero, M.P., Alegre, S. \& Girona, J. (2000): Influence of regulated deficit irrigation strategies applied to olive trees (Arbequina cultivar) on oil yield and oil composition during the fruit ripening period. J. Sci. Fd Agric., 80, 2037-2043. 
Ocakoglu, D., Tokatli, F., Ozen, B. \& Korel, F. (2009): Distribution of simple phenols, phenolic acids and flavonoids in Turkish monovarietal extra virgin olive oils for two harvest years. Fd Chem., 113, 401-410.

Ozkan, G., DaĞDelen, A. \& Erbay, B. (2008): Ayvalık, Domat ve Gemlik Zeytin Çeşitlerinden Elde Edilen Natürel Sızma Zeytinyağlarının Bazı Fiziksel Özellikleri ve Pigment Miktarları Üzerine Hasat Zamanının Etkisi. (Effect of harvest time on some physical properties and pigments of virgin olive oil from Ayvalik, Domat, and Gemlik olive varieties.) Hasad Glda, 24, 44-49.

Papadopoulos, G. \& Boskou, D. (1991): Antioxidant effect of natural phenols on olive oil. J. Am. Oil Chem. Soc., $68,669-671$.

Pokorny, J., Kalinova, L. \& Dysseler, P. (1995): Determination of chlorophyll pigments in crude vegetable oils. Pure Appl. Chem., 67, 1781-1787.

Rotondi, A., Bendini, A., Cerretani, L., Mari, M., Lercker, G. \& Toschi, T.G. (2004): Effect of olive ripening degree on the oxidative stability and organoleptic properties of Cv. Nostrana di Brisighella extra virgin olive oil. J. Agric. Fd Chem., 52, 3649-3654.

Singleton, V.L. \& Rossi, J.R. (1965): Colorimetry of total phenolics with phosphomolibdic-phosphothungstic acid. Am. J. Enology Viticult., 16, 144-158. 